\title{
Growth curves for Ile de France female sheep raised in feedlot
}

\section{Curvas de crescimento de fêmeas da raça Ile de France criadas em confinamento}

\author{
Raphael Patrick Moreira ${ }^{1}$; Victor Breno Pedrosa ${ }^{2 *}$; Paula Roberta Falcão ${ }^{1}$; \\ Michelli de Fátima Sieklicki ${ }^{1}$; Caroline Gomes Rocha ${ }^{1}$; \\ Izaltino Cordeiro dos Santos ${ }^{3}$; Evandro Maia Ferreira ${ }^{2}$; Adriana de Souza Martins ${ }^{2}$
}

\begin{abstract}
The objective of the present study was to analize the non-linear models that best fit the growth of ewes Ile de France. The experiment was conducted in school farm Capão da Onça, located in city of Ponta Grossa - PR and so, were used data on weight at birth to 210 days of age of 34 females of the breed Ile de France. The animals showed mean weight at birth (PN) of 4,58 kilograms, weaning weight (P60) of 19,58 kilograms and weight at 210 days (P210) equal to 43,18 kilograms, providing daily weight gain (GMD) equal to $0,183 \mathrm{~kg} /$ day. The non-linear models used were: Brody, Von Bentarlanffy, Logístic and Gompertz, presenting results, respectively, of $33.5453 ; 33.7120 ; 33.6714$ and 33.8836 for Error Mean Square (EMS) and $0.9650 ; 0.8302 ; 0.9649$ and 0.9647 for coefficient of determination $\left(\mathrm{R}^{2}\right)$. All models tended to describe accordingly the curve of animals growth, but, according to the methods adopted to select the most appropriate model, Von Bertarlanffy showed the best fit. All models presented high and negative correlation between the $\mathrm{A}$ and $\mathrm{k}$ parameters, indicating that the most precocious animals are less likely to reach elevated weights for 210 days of age.
\end{abstract}

Key words: Intensive system, nonlinear models, precocity, weight development

\section{Resumo}

O objetivo do presente trabalho foi analisar os modelos não lineares que melhor se ajustam ao crescimento de fêmeas da raça Ile de France. O experimento foi conduzido na Fazenda Escola Capão da Onça, localizada no município de Ponta Grossa - PR e para tanto, foram utilizados dados de peso ao nascimento até os 210 dias de idade de 34 fêmeas da raça Ile de France. Os animais apresentaram médias de peso ao nascer (PN) de 4,58 kg, peso a desmama (P60) de 19,58 kg e peso aos 210 dias (P210) igual a 43,18 kg, proporcionando ganho de peso médio diário do nascimento aos 210 dias (GMD) igual a $0,183 \mathrm{~kg} /$ dia. Os modelos não lineares utilizados foram: Brody, Von Bentarlanffy, Logístico e Gompertz, apresentando resultados, respectivamente, de 33,5453; 33,7120; 33,6714 e 33,8836 para o Quadrado Médio do Resíduo (QMR) e de 0,9650; 0,8302; 0,9649 e 0,9647 para o Coeficiente de Determinação $\left(\mathrm{R}^{2}\right)$. Todos os modelos tenderam a descrever adequadamente a curva de crescimento destes animais, porém, de acordo com os métodos adotados para escolha do modelo mais adequado, Von Bertarlanffy apresentou o melhor ajuste. Todos os modelos demonstraram correlação alta e negativa

\footnotetext{
${ }^{1}$ Discentes do Curso de Graduação em Zootecnia, Universidade Estadual de Ponta Grossa, UEPG, Uvaranas, Ponta Grossa, PR, Brasil. E-mail: raphaelmoreira@zootecnista.com.br; paulaffalcao@hotmail.com; mikasieklicki_21@hotmail.com; cgomesr@ hotmail.com

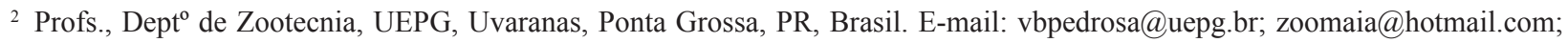
dri_261@yahoo.com.br

3 Gerente de Pecuária, Fazenda Escola da UEPG, Uvaranas, Ponta Grossa, PR, Brasil. E-mail: i.cordeiro@uol.com.br

* Author for correspondence
} 
entre os parâmetros A e k, indicando que animais mais precoces possuem menor probabilidade de atingir pesos mais elevados aos 210 dias de idade.

Palavras-chave: Desenvolvimento ponderal, modelos não lineares, precocidade, sistema intensivo

\section{Introduction}

The Brazilian sheep flock has shown continued expansion in recent years (IBGE, 2012), especially in the southern part of the country. The state of Paraná, in this context, has the potential to increase the number of animals raised for the purpose of producing lambs, starting from specialized breeds like Ile de France. According to Moreno et al. (2010), this breed provides young animals with good carcass yield and rapid muscle development.

However, according to Teixeira et al. (2011), the most important information for the evaluation and selection of sheep are body weights measured during the growth period. This fact makes the adjustment of growth functions that relate weight and age a fundamental tool in the planning of animal production, as it allows obtaining accurate information on animal weight gain, as well as future prognostic information for animals of the same racial group under the same environmental conditions.

One of the methods used to evaluate the development efficiency of sheep is the use of growth curves. Through the use of animal weight joined with the age, it becomes possible to prescribe a large number of measurements in some parameters. Therefore, it is possible to get various information about the weight gain, and also information on the future development of the same breed in the same environmental aspects (PACHECO; QUIRINO, 2008). For these reasons, nonlinear models have been used to adjust the relationship between size and age of the animals based on Richard function, indicating an infinite number of possibilities, including Brody, Von Bertalanffy, Gompertz, and Logistic functions (FITZHUGH JUNIOR, 1976).

According to Sarmento et al. (2006), it is not known precisely what curve adequately describes the body growth of sheep, since many variables modify the weight development of this species, ranging from the different environment to different breeds. Thus, this study aimed to analyze nonlinear models that better fit the growth curve of Ile de France females and best assist the creator in the management of herds.

\section{Material and Methods}

The experiment was carried out at the School Farm Capão da Onça (FESCON) located at latitude $25^{\circ}$ 05'49" South and longitude 50 03 ' 11 " West belonging to the Ponta Grossa State University (UEPG) in Ponta Grossa city, PR. The climate of the region is humid subtropical mesothermal $(\mathrm{Cfb})$ according to the Köppen classification, with an average temperature in winter of $13{ }^{\circ} \mathrm{C}$ with frost and $21^{\circ} \mathrm{C}$ in the summer. The average rainfall is 1,600 to $1,800 \mathrm{~mm}$ per year, with an average annual temperature between 17 and $18^{\circ} \mathrm{C}$ and annual relative humidity of 70 to $75 \%$. The soil of the area is characterized as a Eutric Cambisol with sandy texture (EMBRAPA, 2006). The FESCON area is 312.11 ha, including 6 ha intended for intensive system to sheep meat production.

Thirty-four Ile de France female lambs were used in this experiment and weighed monthly from birth to 210 days old. The weight measurements were performed in the morning, with the animals fasted for 12 hours. Female lambs were feedlot since birth until 210 days old. The animals remained fully with their mothers until 30 days old. From 30 to 60 days of age, the lambs remained with their mothers only in the evening. The animals were weaned at 60 days old and housed in stalls separated from sheep.

The lambs received concentrate four times a day on a $3 \% \mathrm{LW}$ (live weight) average starting at 
10 days of age. The concentrate was composed of the following dry matter (DM) percentages: ground corn $(57.0 \%)$, soybean meal $(15.1 \%)$, wheat bran (5.0\%), ammonium chloride $(0.5 \%)$, limestone $(1.2 \%)$, and vitamin and mineral supplement (1.2\%). Furthermore, corn silage (20\% DM) was available daily in an amount equivalent to $1.5 \mathrm{~kg} /$ animal. The chemical composition of the diet corresponded to $60.1 \% \mathrm{DM}$ (\% of original matter), $16.2 \%$ crude protein, $3.2 \%$ ether extract, and $22.2 \%$ neutral detergent fiber. The vitamin supplement composition was $7.5 \% \mathrm{P}, 13.4 \% \mathrm{Ca}, 1.0 \% \mathrm{Mg}, 7 \%$ S, 14.5\% Na, 500 ppm Fe, 300 ppm Cu, 4600 ppm $\mathrm{Zn}$, and $15 \mathrm{ppm}$ Se.

For growth curves determination, we used Brody, Logistic, Von Bertalanffy, and Gompertz models, which may be represented as follows: Von Bertalanffy: $\mathrm{Y}=\mathrm{A}(1-\mathrm{Be}-\mathrm{kt})^{3}+\varepsilon$; Brody: $\mathrm{Y}=$ $\mathrm{A}(1-\mathrm{Be}-\mathrm{kt})+\varepsilon$; Gompertz: $\mathrm{y}=\mathrm{AeBe}(-\mathrm{kt})+\varepsilon$; and Logistic: $\mathrm{y}=\mathrm{A}(1+\mathrm{e}-\mathrm{kt})-\mathrm{m}+\varepsilon$,

where:

$\mathrm{Y}=$ body weight at age $\mathrm{t}$;

$\mathrm{A}=$ asymptotic estimate of the value or weight, not being the highest weight that the animal can reach, but the average weight maturity free of seasonal variations;

$\mathrm{B}=$ integration constant related to the initial weights, established by the initial values of $\mathrm{Y}$ and $\mathrm{t}$;

$\mathrm{K}=$ maturity rate, which is the change in weight compared to the weight at maturity;

$\mathrm{m}=$ provides a form to the curve and therefore determines in which proportion of asymptotic value (A) is the inflection point thereof;

In nonlinear models, it is not allowed to solve equation systems formed directly, as in the linear model, because the resolution of the system is dependent on its own parameters to be estimated. Thus, it is used an iterative process to obtain estimates of the parameters, which begins with initial values allocated to its own parameters to be estimated. The sum square error is calculated to obtain an updated set of estimates until the procedure to converge to a final vector estimate, which obtains the minimum sum square error (SARMENTO et al., 2006).

The criteria used to choose the model that best described the growth curve were: error mean square (EMS), calculated by dividing the sum of squares of the error by the number of observations, which is the estimator of maximum likelihood of residual variance so that it could compare the EMS of different models, as they have different numbers of parameters to be estimated; and the coefficient of determination $\left(\mathrm{R}^{2}\right)$, calculated as the square of the correlation between observed and estimated weights by means of a linear regression analysis considering the predicted weight by the nonlinear model as a dependent variable and the observed weight of the animal as an independent variable (SOUZA et al., 2011).

After the choice of the best model, the absolute growth rate (AGR) was calculated, obtained from the first derivative of the adjusted model selected with respect to time $(\partial \mathrm{Y} / \partial \mathrm{t})$ (MALHADO et al., 2008). The AGR can be interpreted by the obtained weight gain per unit of time, and thus represents the average daily weight gain, estimated along the trajectory of growth evaluated. The parameters of the models were estimated by the Marquardt method modified by SAS statistical software NLIN procedure using convergence criteria 10-8. The Pearson correlations between the parameters were estimated by the CORR procedure of SAS statistical package, version 9.1 (STATISTICAL ANALYSIS SYSTEM, 2009).

\section{Results and Discussion}

The animals showed a moderate growth rate in the period (Table 1), with an average weight at birth (PN) equal to $4.58 \mathrm{~kg}$ and weight at 210 days (P210) equal to $43.18 \mathrm{~kg}$, with an average daily gain of $0.183 \mathrm{~kg} /$ day. 
Table 1. Descriptive statistics of the live weight of Ile de France female sheep until 210 days old.

\begin{tabular}{ccccc}
\hline Variable & Mean $(\mathrm{kg})$ & Min $(\mathrm{kg})$ & Max $(\mathrm{kg})$ & S.D. \\
\hline PN & 4,58 & 3,00 & 6,00 & 0,80 \\
P30 & 13,58 & 10,90 & 19,50 & 3,37 \\
P60 & 19,58 & 11,00 & 28,70 & 3,76 \\
P90 & 27,99 & 14,10 & 40,20 & 5,71 \\
P120 & 33,98 & 21,00 & 43,00 & 6,26 \\
P150 & 37,08 & 23,50 & 55,00 & 7,76 \\
P180 & 39,67 & 25,10 & 57,50 & 7,49 \\
P210 & 43,18 & 29,20 & 64,50 & 7,39 \\
\hline
\end{tabular}

S.D. - Standard deviation.

In a study with Ile de France lambs weaned at 60 days in confinement, Moreno et al. (2010) obtained a PN of $3.79 \mathrm{~kg}$, P60 of $15.72 \mathrm{~kg}$, and $\mathrm{P} 116$ of $32.80 \mathrm{~kg}$ and these values are in accordance to the results of this study. Ó et al. (2012), working with male sheep in the Valley of Gurgueia in a semi-confined system, had average values for birth weight of $3.38 \mathrm{~kg}$, at 28 days equal to $6.30 \mathrm{~kg}$, at 56 days of $9.40 \mathrm{~kg}$, at 112 days of $13.50 \mathrm{~kg}$, and at 350 days of 25.79 , showing low performance in comparison to Ile de France animals. In contrast, Gastaldello Junior et al. (2010), in studies with male sheep in a feedlot system with high concentrate in combination with monensin, obtained, for slaughter in 143 days, an average weight equal to $37.6 \mathrm{~kg}$. Thus, it can be inferred that the type of system adopted can substantially influence the weight gain of the animals from the early stages of life to the slaughter period for both woolly as woolless animals.

According to the estimates of the parameters for the models evaluated in this study, the Brody model presented the highest value for parameter A, while the lowest value was obtained by the Logistic model (Table 2). The other models presented intermediate values; however, their values were similar to those obtained by the Logistic model. Even though the Brody equation predicted the highest value for A, when graphically compared with the real growth of the animals, it was found that it better predicts the curve in its final part, while the other models tended to underestimate the final weight to a greater or lesser extent (Figure 1). Comparing nonlinear models to describe the growth of crossbred sheep Santa Inês + Texel, Malhado et al. (2008) also found higher values for $\mathrm{A}$ in the Brody model (37.66) and the lowest in the Logistics model (29.14), but with a low magnitude of values, demonstrating that the Ile de France breed tends to have higher values for adult weight.

Compared to the same parameter, Zamproni et al. (2007) got to cross sheep, 15/16 Ile de France + 1/16 Ideal, also higher values for Brody (56.46), and this value is quite similar to that found in the present study due to the high degree of the Ile de France breed in the total composition of the crossbred. This reinforces the information that Ile de France tends to increase the potential of body growth of sheep when introduced into the production system. Another important fact is that the female adult weight has a high positive influence on the weaning weight of lambs (FERNANDES et al., 2001), and a female with a high value for asymptotic weight will produce a lamb with a higher weaning weight, increasing the precocity of animals and the efficiency in obtaining animals for slaughter. 
Figure 1. Weight estimates by age, obtained by Brody, Von Bertalanffy ( a); Gompertz, Logistic ( b ), together with the values observed in Ile de France lambs.
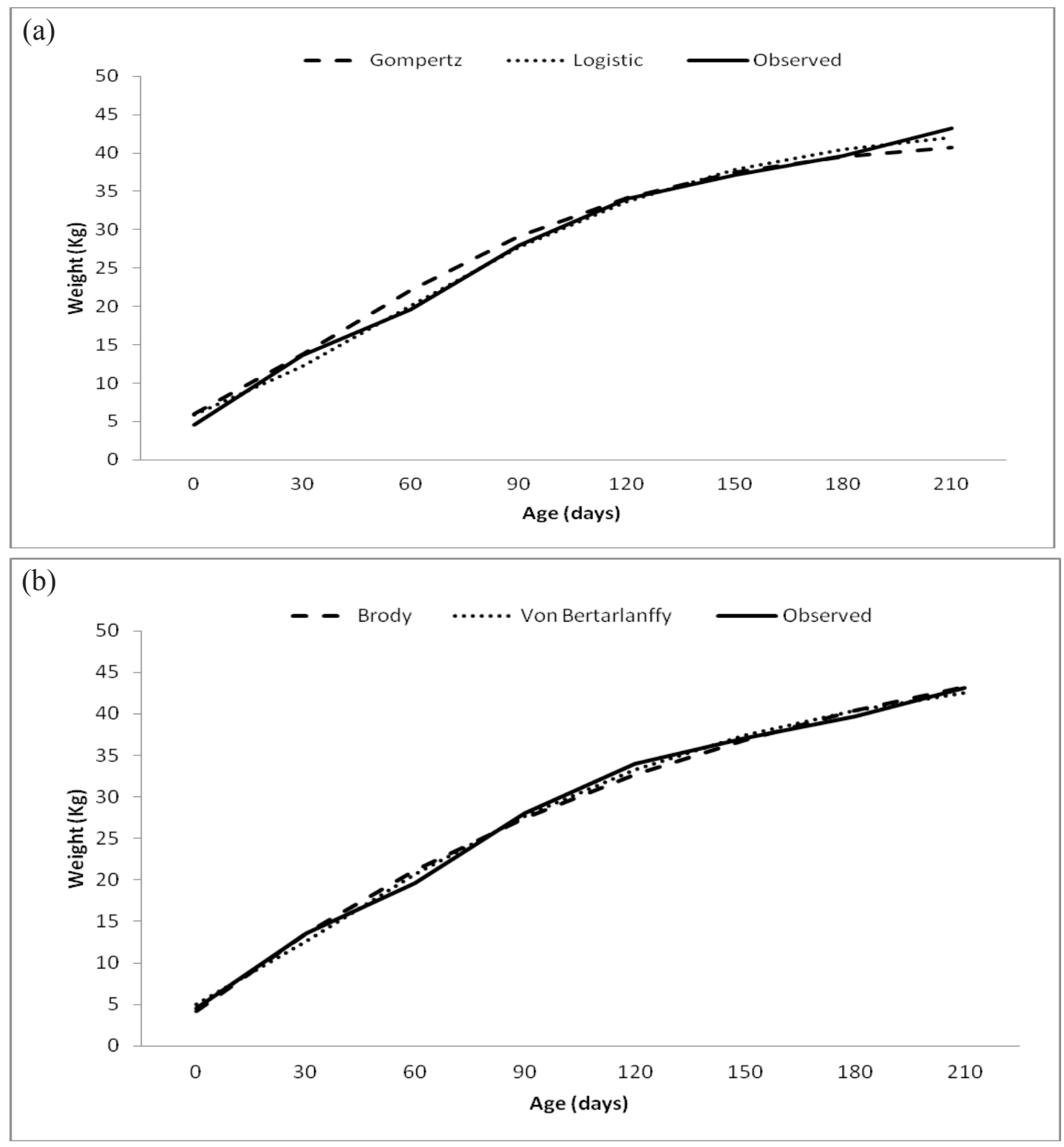

Parameter B, which is an integration constant, represents the degree of maturity of the lamb at birth. Thus, animals that have high values for $B$ have low maturity at birth. The model that determined the highest value for parameter B was Gompertz, followed by Brody and Von Bertalanffy. For the graphical evaluation of the adjusted models compared to the growth observed, the Logistic and Gompertz models overestimated the birth weight values. The Von Bertalanffy and Brody models were closer to the actual birth weights.

Because the birth weight values were similar, we can say that parameter $\mathrm{k}$ is efficient in predicting the growth rate of the animal. Parameter k was higher in the Logistic model compared to the Gompertz, Von Bentarlanffy, and Brody models. The weight is extremely important for the reproductive life of females, since, according to Lôbo et al. (2006), 
females must be covered when they have $60 \%$ of their adult weight. Thus, a high maturation rate indicates reproductively earlier females, which may indicate a greater number of lambs produced in their life. In their study, Zamproni et al. (2007) obtained values of $0.0022,0.0017,0.0015$, and
0.0012 for the Logistic, Gompertz, Von Bertalanffy, and Brody models, respectively, so we see that the Logistic model also estimated higher values for $\mathrm{k}$; however, the growth rate predicted in this study was considerably higher, demonstrating the precocity of the Ile de France breed.

Table 2. Estimates of the parameters, mean square and the coefficient of determination, according to the studied models.

\begin{tabular}{ccccc}
\hline Parameter & \multicolumn{4}{c}{ Model } \\
\hline & Von Bertalanffy & Brody & Gompertz & Logistic \\
\hline A & 47.2878 & 56.3481 & 45.4366 & 44.1657 \\
B & 0.5263 & 0.9249 & 2.1143 & - \\
k & 0.0130 & 0.00657 & 0.0162 & 0.0194 \\
m & - & - & - & 2.9067 \\
Error Mean Square (EMS) & 33.5453 & 33.7120 & 33.6714 & 33.8836 \\
Coefficient of Determination $\left(\mathrm{R}^{2}\right)$ & 0.9650 & 0.8302 & 0.9649 & 0.9647 \\
\hline
\end{tabular}

Parameter $m$ determines the proportion of the asymptotic value, which is the point of inflection of the growth curve. This value was very close to that found by Souza et al. (2011) in Morada Nova with a value of 2.53 .

All models showed good values for the coefficient of determination, being $96.50 \%$ for Von Bertalanffy, $96.49 \%$ for Gompertz, $96.47 \%$ for Logistic, and $83.02 \%$ for Brody, which had the worst fit, since higher values of the coefficient of determination represent the best fit of the model to the data. When analyzing the mean square, we also found that the Von Bertalanffy model was the best fit, followed by the Gompertz, Brody, and Logistic models, where lower values indicate a model higher proximity to an adjusted estimate to the data observed in the experiment. The fact that the Von Bertalanffy model had the highest value of R2 and the lowest EMS indicated the best fit for the data to Ile de France female lambs in a confinement system, followed by the Gompertz, Logistic, and Brody models. Despite the Brody model's ability to accurately estimate the birth weight and weight at the end of the curve, the model showed greater overestimation or underestimation at certain stages of animal development compared to other nonlinear models.

It was observed for all models that there is a decline in growth starting at 30 days of age, but with continued weight gain until 210 days of age. This result can be interpreted not only as a decrease in bone and muscle growth rate but also as a physiological response to the early weaning process, as from the 30th day the animals were separated from their mothers during the daytime. The curve presents a brief rise after the 75 th day in response to the animal's adaptation to the complete process of weaning (Figure 1).

According to growth comparison estimates and the observed data, all models tended to have a similar curve to those observed at 210 days. For females, we should have special attention to the start of their reproductive life, because according to Bartlewski et al. (2002), animals that exhibit cyclicity younger and therefore are selected earlier, tends to increase its productivity. According to 
Pacheco and Quirino (2008), one of the ways to increase the number of lambs produced in the life of a female sheep is to bring forward the age at first calving. Therefore, we can highlight the importance of high weight gain rates of females, because the age at sexual maturity is correlated with their weight, influencing productivity in the life of the array.
Due to better fit, the Von Bertalanffy model was considered to describe the AGR of the lambs. The AGR was obtained through the first derivative of the equation of the model in function of time (Figure 2). Analyzing AGR, it can be noted that the curve growth until it reached the top around 30 days of age, and from this age there was a considerable loss of weight gain coinciding with the animals' separation from their mothers.

Figure 2. Absolute growth rate (AGR) estimated by Von Bertalanffy model for Ile de France female sheep.

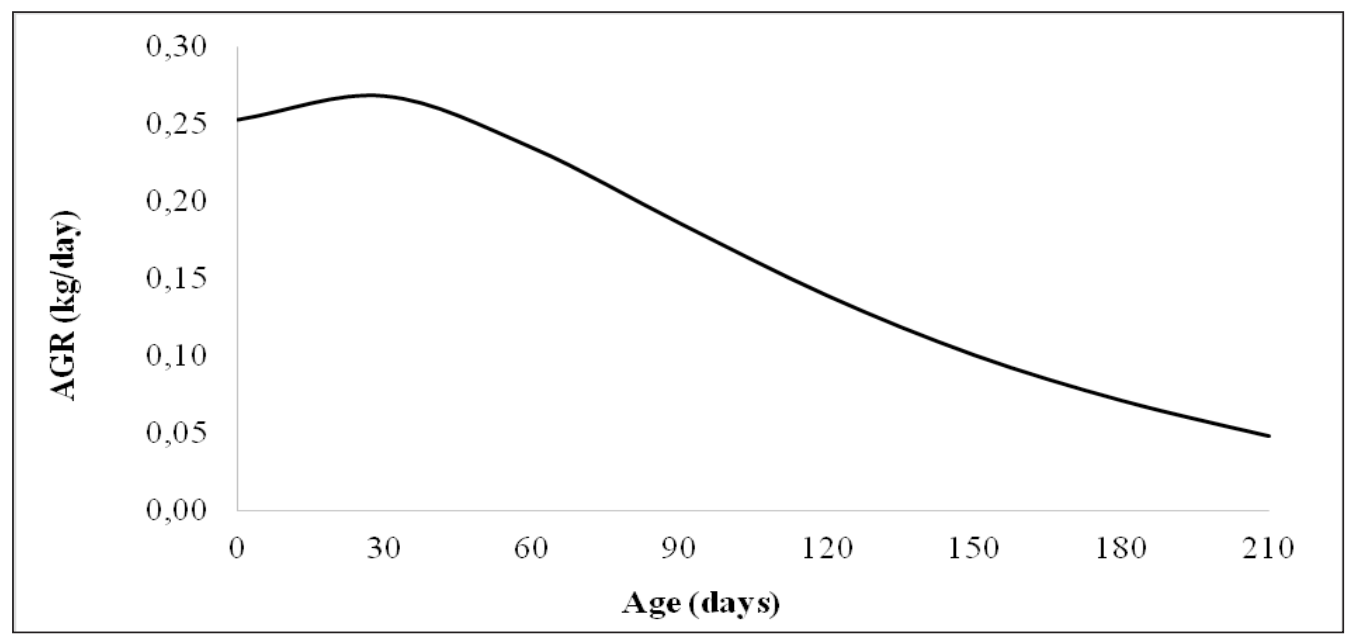

According to Souza et al. (2011), the curve inflection point is important to assist producers in specific food programs. Thus, nutritional strategies for the post-weaning period should be implemented in order to minimize the effects of diet changes, mitigating the decrease in AGR after this stage. The effects of weaning can be ameliorated when associated with good nutritional management of the transition between pre- and post-weaning.

For the correlations between parameters, there was a high negative correlation between $\mathrm{A}$ and Kfor all models, in which the Von Bentalanffy model showed a value of -0.9143 , Brody -0.9783 , Gompertz -0.8727, and Logistic -0.8386. This indicates that animals that have a high growth rate tend to have lower asymptotic weights compared to those that have low rates, which is in agreement with the results obtained by various authors, such as McManus et al. (2003), Sarmento et al. (2006), and Malhado et al. (2008).

\section{Conclusions}

According to the results, all models showed good fit for the growth curve, especially the Von Bertalanffy model, due to the high coefficient of determination and low residual mean square. The use of this model can assist creators in predicting the growth of Ile de France female lambs, and thus facilitate the adequacy of nutritional management and set the best goals for herd breeding. 


\section{References}

BARTLEWSKI, P. M.; BEARD, A. P.; COOK, S. J.; RAWLINGS, N. C. Ovarian activity during sexual maturation and following introduction of the ram to ewe lambs. Small Ruminant Research, Amsterdam, v. 43, n. 1, p. 37-44, 2002.

EMPRESA BRASILEIRA DE PESQUISA AGROPECUÁRIA - EMBRAPA. Sistema Brasileiro de Classificação de Solos. 2. ed. Rio de Janeiro: Centro Nacional de Pesquisa de Solos, 2006. 286 p.

FERNANDES, A. A. O.; BUCHANAN, D.; SELAIVEVILLARROEL, A. B. Avaliação dos fatores ambientais no desenvolvimento corporal de cordeiros deslanados da raça Morada Nova. Revista Brasileira de Zootecnia, Viçosa, MG, v. 30, n. 5, p. 1460-1465, 2001.

FITZHUGH JUNIOR, H. A. Analysis of growth curves and strategies for altering their shapes. Journal of Animal Science, Champaign, v. 42, n. 4, p. 1036-1051, apr. 1976.

GASTALDELLO JUNIOR, A. L.; PIRES, A. V.; SUSIN, I.; MENDES, C. Q.; FERREIRA, E. M.; MOURÃO, G.

B. Desempenho e características de carcaça de cordeiros alimentados com dietas contendo alta proporção de concentrado adicionadas de agentes tamponantes. Revista Brasileira de Zootecnia, Viçosa, MG, v. 39, n. 3, p. 556-562, 2010.

INSTITUTO BRASILEIRO DE GEOGRAFIA E ESTATÍSTICA - IBGE. Produção da pecuária municipal. Rio de Janeiro: IBGE, 2012. Disponível em: <ftp://ftp. ibge.gov.br/Producao_Pecuaria/Producao_da_Pecuaria_ Municipal/2012/ppm2012.pdf>. Acesso em: 18 nov. 2012.

LÔBO, R. N. B.; VILLELA, L. C. V.; LÔBO, A. M. B. O.; PASSOS, J. R. S.; OLIVEIRA, A. A. Parâmetros genéticos de características estimadas da curva de crescimento de ovinos da raça Santa Inês. Revista Brasileira de Zootecnia, Viçosa, MG, v. 35, n. 3, p. 10121019, 2006.

MALHADO, C. H. M.; CARNEIRO, P. L. S.; SANTOS, P. F.; AZEVEDO, D. M. M.; SOUZA, J. C.; AFFONSO, P. R. M. Curva de crescimento em ovinos mestiços Santa Inês x Texel criados no Sudoeste do Estado da Bahia. Revista Brasileira de Saúde Produção Animal, Salvador, v. 9, n. 2, p. 210-218, 2008.
MCMANUS, C.; EVANGELISTA, C.; COSTA FERNANDES, L. A.; MIRANDA, R. M.; MORENOBERNAL, F. E.; SANTOS, N. R. Curvas de crescimento de ovinos bergamácia criados no Distrito Federal. Revista Brasileira de Zootecnia, Viçosa, MG, v. 32, n. 5, p. 12071212, 2003.

MORENO, G. M. B.; SILVA SOBRINHO, A. G.; ROSSI, R. C.; PEREZ, H. L.; LEÃO, A. G.; ZEOLA, N. M. B. L.; SOUZA JÚNIOR, S. C. Desempenho e rendimentos de carcaça de cordeiros Ile de France desmamados com diferentes idades. Revista Brasileira de Saúde Produção Animal, Salvador, v. 11, n. 4, p. 1105-1116, out./dez. 2010.

Ó, A. O. do; RÊGO NETO, A.; SANTOS, G. V.; SARMENTO, J. L. R.; BIAGIOTTI, D.; SOUSA, J. E. R. Curva de crescimento de ovinos Santa Inês no Vale do Gurgueia. Revista Brasileira de Saúde Produção Animal, Salvador, v. 13, n. 4, p. 912-922, out./dez. 2012.

PACHECO, A.; QUIRINO, C. R. Estudo das características de crescimento em ovinos. Pubvet, Londrina, v. 2, n. 29, p. 1982-1263, 2008.

SARMENTO, J. L. R.; REZAZZI, A. J.; SOUZA, W. H.; TORRES R. A.; BREDA1, F. C.; MENEZES, G. R. O. Estudo da curva de crescimento de ovinos Santa Inês. Revista Brasileira de Zootecnia, Viçosa, MG, v. 35, n. 1, p. 435-442, 2006.

SOUZA, L. A.; CARNEIRO, P. L. S.; MALHADO, C. H. M.; PAIVA, S. R.; CAIRES, D. N.; BARRETO, D. L. F. Curvas de crescimento em ovinos da raça morada nova criados no estado da Bahia. Revista Brasileira de Zootecnia, Viçosa, MG, v. 40, n. 8, p. 1700-1705, 2011.

STATISTICAL ANALYSIS SYSTEM - SAS. User's guide. Version 9. Cary: SAS Institute, 2009. CD-ROM.

TEIXEIRA, M. C.; VILLARROEL, A. B.; PEREIRA, E. S.; OLIVEIRA, S. M. P.; ALBUQUERQUE, I. A.; MIZUBUTI, I. Y. Curvas de crescimento de cordeiros oriundos de três sistemas de produção na Região Nordeste do Brasil. Semina: Ciências Agrárias, Londrina, v. 33, n. 5, p. 2011-2018, 2011.

ZAMPRONI, V.; PEREZ, H. L.; MORENO, G. M. B.; GARCIA SOBRINHO, A.; QUEIROZ, S. A.; THOLON, P. Modelos de curva de crescimento para ovinos de diferentes grupos genéticos entre as raças Ideal e Ile de France. In: ZOOTEC, CONGRESSO BRASILEIRO DE ZOOTECNIA, 44., 2007, Londrina. Anais... Londrina: Associação Brasileira de Zootecnia, 2007. CD-ROM. 